\title{
A new cyanobacterium from the Everglades, Florida - Chamaethrix gen. nov.
}

\author{
Petr Dvořák*1, Petr Hašler ${ }^{1}$, Petra Pitelkován, Petra Tabáková ${ }^{1}$, Dale A. \\ CAsamatta $^{3} \&$ Aloisie PoulíčKová ${ }^{1}$
}

\author{
${ }^{1}$ Department of Botany, Faculty of Science, Palacký University Olomouc, Šlechtitelů 27, CZ-783 71 Olomouc \\ Czech Republic; *Corresponding authore-mail:p.dvorak@upol.cz \\ ${ }^{2}$ Department of Biology, Faculty of Science, University of Hradec Králové, Hradec Králové, Czech Republic \\ ${ }^{3}$ Department of Biology, University of North Florida, 1 UNF Drive, Jacksonville, Florida, FL 32224, USA
}

\begin{abstract}
Cyanobacteria are cosmopolitan group of phototrophic microbes with significant contributions to global primary production. However, their biodiversity, especially in tropical areas, is still largely unexplored. In this paper, we used a combination of molecular and morphological data to characterize a filamentous cyanobacterium isolated from a soil crust in the Everglades National Park in Florida. It is morphologically similar to the ubiquitous, polyphyletic Leptolyngbya, but phylogenetic analysis of the 16S rRNA gene and secondary structures of the 16S-23S ITS region revealed that our isolates form a monophyletic clade unrelated to Leptolyngbya sensu stricto. Apart from its phylogenetic position, we found that the strain possesses a unique combination of morphological and molecular characters, which have not been found in any other Leptolyngbya species. Due to these characteristics, together with its subtropical origin, we erect new monospecific genus Chamaethrix.
\end{abstract}

Key words: Leptolygbya, new genus, phylogeny, soil crust, subtropical region, taxonomy

\section{INTRODUCTION}

The evolutionary history of the cyanobacteria is extremely entangled and interlaced with myriad examples of morphological and genetic convergence. These events have given rise to the polyphyletic relationships within a majority of cyanobacterial genera, necessitating taxonomic revisions and description of many new taxa (e.g. KomÁRek et al. 2014; DvořÁk et al. 2015). Moreover, morphologically simple genera with wide ecological and biogeographical ranges, such as the unicellular Synechococcus or filamentous Leptolyngbya, may mask numerous polyphyletic lineages (OsorioSAntos et al. 2014; Miscoe et al. 2016; DvořÁK et al. 2017). Mechanisms responsible for this pattern are largely enigmatic. However, DvořÁk et al. (2014) proposed a model of serial convergence, which assumes that the dynamic nature of cyanobacterial genomes, particularly due to extensive horizontal (lateral) gene transfer that generates frequent convergence events, may lead to this extensive polyphyly.

While most cyanobacterial diversity has been described from temperate zones, tropical and subtropical areas may possess a rich biodiversity that has been underestimated by researchers (e.g. FIORE et al.
2007). Recent acknowledgement of this hole in our knowledge of tropical and subtropical taxa has been recognized (HAŠLER et al. 2014, 2017; Miscoe et al. 2016), leading to the erection of numerous new lineages (e.g., Potamolinea Martins \& Branco (2016), Gloeomargarita MoreIRE et al. (2017)).

The genus Leptolyngbya was erected by AnAgNOSTIDIS \& KOMÁREK (1988), encompassing much of the LPP-group B earlier proposed by RIPPKA et al. (1979). It is a group of filamentous cyanobacteria with a cosmopolitan distribution. Filaments are thin (up to $3.5 \mu \mathrm{m}$ ), with some species possessing sheaths and pseudobranching, aerotopes are not present, and reproduction by fragmentation or hormogonia production (KOMÁREK \& ANAGNOSTIDIS, 2005). It has been noted by KOMÁREK \& ANAGNOSTIDis (2005) that it is one of the most problematic cyanobacterial genera in terms of systematic assessments, and needs to be subsequently divided into several genera. While some revisions of this wide-spread genus have begun (e.g., Nodosilinea Perkerson et al. 2011; Oculatella ZAMmiT et al. 2012 and Stenomitos Miscoe et al. 2016), much work remains.

In this paper, we present a new Leptolyngbyalike cyanobacterium, isolated from a soil crust in Everglades National Park, Florida, USA, characterized 
using a combination of molecular and morphological data.

\section{Material ANd Methods}

Strain isolation. Samples were collected from a soil crust in the Grass Prairie from the Everglades National Park (GPS: N25²4'9.668"; W80³9'17.502") December 30, 2013. Strains were isolated from fresh samples using standard isolation techniques (ANDERSON, 2005) and maintained in $90 \mathrm{~mm}$ Petri dishes under the following conditions: temperature $26 \pm 1{ }^{\circ} \mathrm{C}$, illumination $20 \mu \mathrm{mol} \cdot \mathrm{m}^{-2} \cdot \mathrm{s}^{-1}$, light regime $12 \mathrm{~h}$ light $/ 12 \mathrm{~h}$ dark, and liquid Zehnder medium ( $\mathrm{Z}$ medium; Staub 1961).

Morphological assessment. The morphology of the strains were analyzed using a light microscope Zeiss AxioImager (objectives EC Plan-Neofluar 40x/ 1.3 N.A., oil immersion, DIC; Plan-Apochromat 100x/1.4 N.A., oil immersion, DIC) with a high resolution camera (AxioCam HRc 13MPx). A total of 100 cells were measured for cell dimensions, morphological assessment (e.g., cell shape, terminal cells, granulation), reproduction, and sheath production.

PCR amplification and sequencing. Genomic DNA was isolated from approximately $50 \mathrm{mg}$ of fresh biomass using an UltraClean Microbial DNA Isolation Kit (MOBIO, Carlsbad, CA, USA) following the manufacturer's manual. DNA quality and consistency was inspected on GelRed (Biotinum Inc., Hayward, CA, USA) stained $1.5 \%$ agarose gel. DNA was quantified using the NanoDrop 1000 (Thermo Fisher Scientific, Wilmington, DE, USA).

Partial 16S rRNA and the whole 16S-23S ITS was amplified using the PCR primers forward P2 (5'-GGGGAATTTTCCGCAATGGG-3 $3^{\circ}$ ) and reverse P1 (5'- CTCTGTGTGCCTAGGTATCC $-3^{\circ}$ ), as previously described in BOYER et al. (2002). The PCR reaction, with a total volume of $40 \mu \mathrm{L}$, contained: $17 \mu \mathrm{L}$ of sterile water, $1 \mu \mathrm{L}$ of each primer $(0.01$ mM concentration), $20 \mu \mathrm{L}$ FastStart PCR Master (Roche Diagnostics $\mathrm{GmbH}$, Mannheim, Germany), and $1 \mu \mathrm{L}$ of template DNA (50 $\left.\mathrm{ng} \cdot \mu \mathrm{L}^{-1}\right)$. PCR amplification was performed as described in Dvoř́́K et al. (2012). PCR products were purified using GenElute PCR Clean-up Kit (Sigma-Aldrich, Prague, Czech Republic).

The same pair of primers as for PCR amplification was used for sequencing. Additionally, two other internal primers were added P5 (5'-TGTACACACCGCCCGTC- $\left.3^{\circ}\right)$, and P8 (5'AAGGAGGTGATCCAGCCACA-3') (Boyer et al. 2001, 2002). Sequencher 5.1 was used to assemble and proofread a sequence (Gene Codes Corporation, Ann Arbor, MI, USA), which was deposited to GenBank (http://www.ncbi.nlm.nih. gov/) under the accession number MF133444.

Phylogenetic analyses. BLAST results (http://blast.ncbi. nlm.nih.gov/Blast.cgi) from the NCBI database (http://www. ncbi.nlm.nih.gov/) were used to select 16S rRNA sequences most similar to our strain, with additional reference sequences of Leptolyngbya added. Multiple sequence alignment was performed in MEGA 6 (TAMURA et al. 2013) using the Muscle algorithm (EDGAR 2004). The tree was rooted with Gloeobacter violaceus. The most appropriate model for Bayesian inference was determined in jModelTest 0.1.1 (PosADA 2008) based on both the Bayesian and the Akaike Information Cri- terion as following: HKY model with gamma distributed variation across sites. The Bayesian inference was performed in MrBayes 3.2.3 (Ronquist \& HueLsenbeck 2003) with two separate runs (each with 3 heated and 1 cold chains) for $50,000,000$ generations. The sampling frequency was each $5000^{\text {th }}$ generation and $25 \%$ trees were discarded as burn-in. The consensus tree was constructed using $50 \%$ majority rule. Maximum likelihood analysis was performed in RaxML 8.0.2 (STAMATAKIS 2006) with a GTRGAMMA model. Maximum parsimony analyses were performed in PAUP* $4.0 \mathrm{~b} 10$ (SwOFFORD 2002), with gaps treated as missing data. All analyses were tested using bootstrapping with 1000 replicates. Genetic similarity of the sequences was compared using Clustal X 2.0 (LARKIN et al. 2007). The secondary structures of D1-D1' helix and Box-B helix ITS regions were inferred with the Mfold web server version 3.5 (ZUCKER 2003) with temperature set to default $\left(37^{\circ} \mathrm{C}\right)$.

\section{Results}

\section{Chamaethrix gen. nov.}

Description: Filaments solitary or in mats, straight or undulate, occasionally falsely branched (Scytonema type); sheaths usually colorless, distinct, firm, thin or thick, seldom intensely colored (brownish to black). Trichomes unconstricted or slightly constricted at cross-walls, without meristematic zones, occasionally two tightly attached in a common sheath (Blennothrix type). Cells rectangular, isodiametric to longer than wide. Apical cells rounded to conical. Reproduction by disintegration into short parts (hormogonia), usually by the help of necridic cells.

Type species: Chamaethrix vaginata spec. nov.

Ethymology: the generic epithet Chamaethrix originates from Greek Chamae - on the ground, creeping and thrix - hair

\section{Chamaethrix vaginata sp. nov. (Fig. 1)}

Description: Thallus green, blue-green or blackish in fine mats or aggregates, filaments long, straight, bent to undulated, $4.15 \pm 0.52 \mu \mathrm{m}$ in diameter, occasionally falsely branched (Scytonema type). Sheath usually colorless, distinct, firm, thin or thick when intensely violet to dark violet, brownish to black. Trichomes unconstricted or slightly constricted at cross-walls, without meristematic zones, occasionally two tightly attached in a common sheath (Blennothrix type). Cells rectangular, isodiametric to longer than wide, $3.74 \pm 1.34 \mu \mathrm{m}$ length, $2.8 \pm 0.46 \mu \mathrm{m}$ width, blue-green with distinct peripheral chromatoplasma and inner centroplasma, often granulated. Apical cells rounded to conical. Reproduction by disintegration into short parts (hormogonia), usually by the help of necridic cells.

Holotype: Holotype OLM Botany 24: Lichenes and others No. 9225, dried sample is deposited in Regional Museum in Olomouc, Czech Republic.

Type strain: F12/109, deposited at the culture Collection of Department of Botany, Palacký University in 

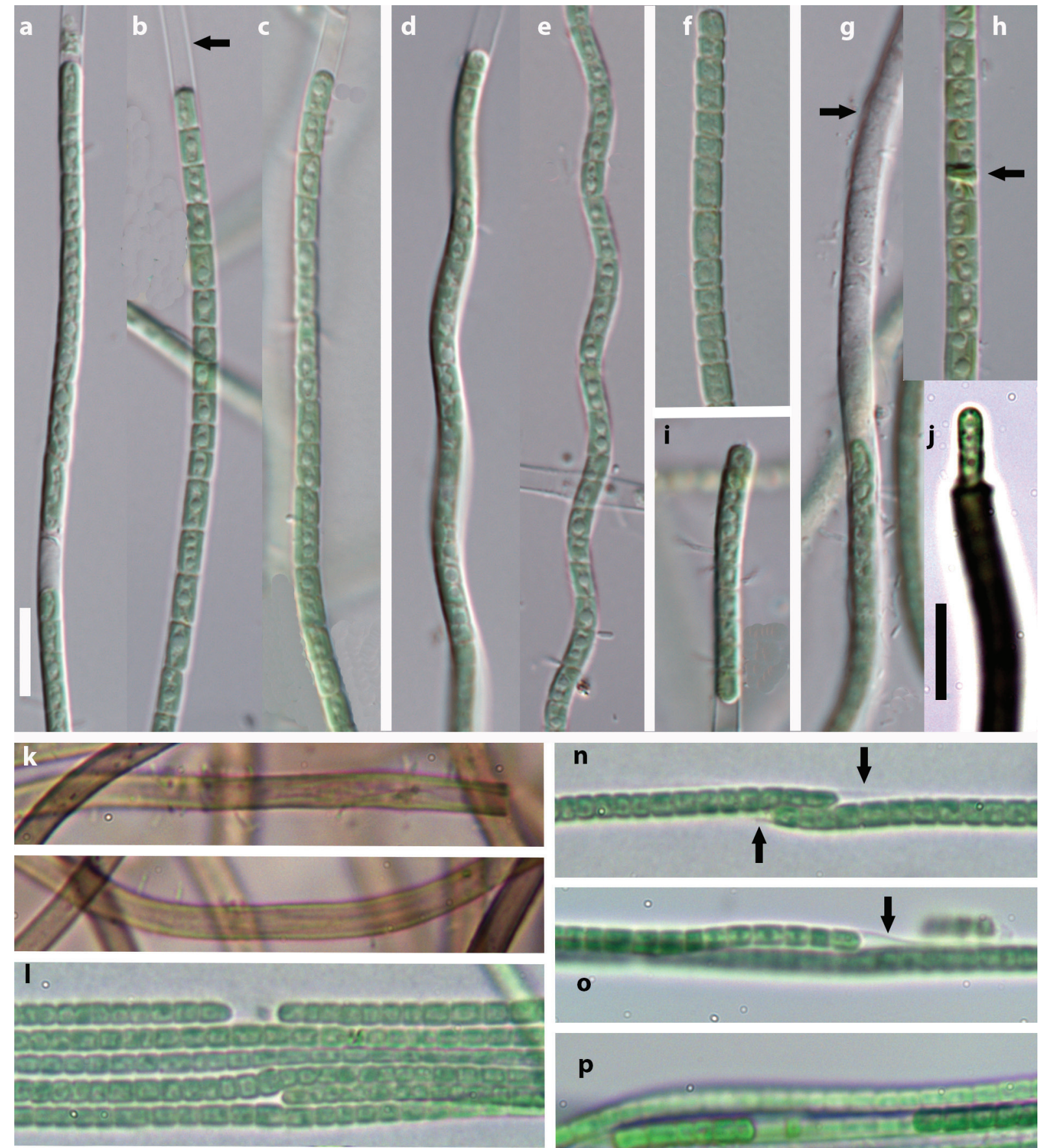

\section{o}
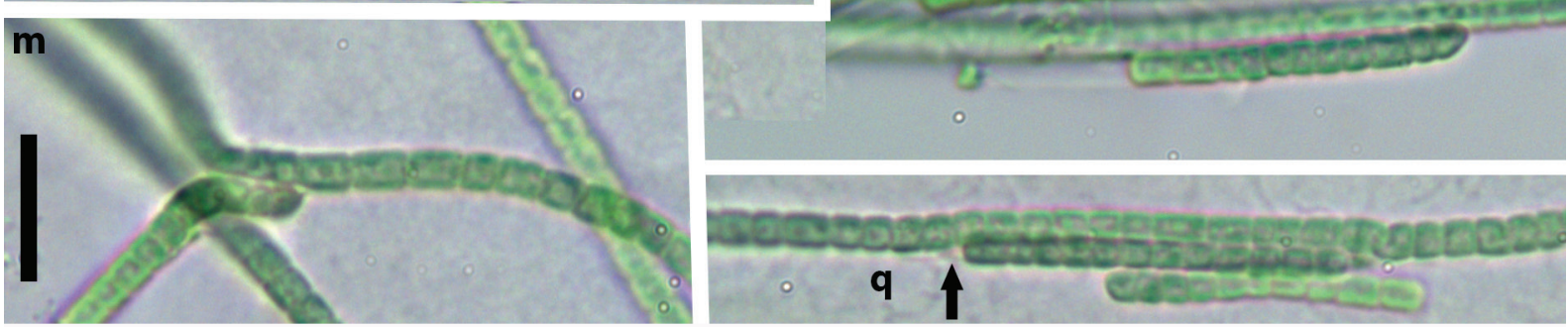

Fig. 1. Morphological variability of Chamaethrix vaginata, holotype, iconotype: single filaments straight to undulated (e, f) with prominent sheath, colourless $(a-d, g, i)$ or blackish (j); with necridic cell $(h)$; empty sheath from died material $(k)$; trichomes with thin sheath growing in parallel bundle (1); pseudo-branching (m); Blennothrix-like attachment of two trichomes in common sheath (n-q). Scale bar $10 \mu \mathrm{m}$.

Olomouc, Czech Republic.

Etymology: A species name refers to the distinct sheaths.

Type locality: Grass Prairie in Everglades National
Park (GPS: N2524'9.668"; W80³9'17.502"), Florida, United States of America

Habitat: soil crust

Iconotype: Fig. 1 


\section{Differential description}

Chamaethrix vaginata shares most morphological features with members of the genus Leptolyngbya such as cell size and shape, trichome organization, presence of sheath, false branching, and necridic cells. In addition, $C$. vaginata exhibits a high variability of filament development. Filament aggregations contain a variable number of individuals resembling several genera of filamentous cyanobacteria. Two or more trichomes in a common sheath make Chamaethrix different feature from Leptolyngbya. Specific formation of lateral trichomes in common sheath makes it similar to members of the genus Blennothrix. On the other hand, cells correspond more to members of the order Synechococcales than to Oscillatoriales (e.g., cell dimensions roughly isodimetric to longer than wide). With respect to combination of features mentioned above, we consider Chamaethrix vaginata unique taxon among known cyanobacteria.

\section{Phylogenetic placement and ITS secondary struc- tures}

Generally, the $16 \mathrm{~S}$ tree topology resembled previously published phylogenies (e.g. KOMÁREK et al. 2014; OsoRIO-SANTOS et al. 2014; Fig. 2). For example, phylogenetically well-characterized genera such as Nodosilinea, Oculatella, and Microcoleus formed monophyletic and well supported clades. On the other hand, our phylogeny provided more evidence of the polyphyletic nature of the order Synechococcales (sensu KomÁREK et al. 2014). In our analysis of the $16 \mathrm{~S}$ gene, C. vaginata formed a moderately supported clade with Leptolyngbya sp. CR 17M, an isolate from a hot spring in Costa Rica, and distant from Leptolyngbya sensu stricto (Fig. 2).

The phylogeny revealed 13 polyphyletic lineages within the genus "Leptolyngbya" sensu lato (as morphologically defined by KomÁReK, AnAgnosTIDIS 2005). Chamaethrix appeared in one of those clades with other Leptolyngbya-like cyanobacteria (Leptolyngbya sp. strains - BN43, BN22, S1C4 and CR_17M), Oscillatoriales cyanobacterium JSC-12, one uncultured clone Mat-CYANO-S10 and Arthronema africanum. The closest relative to Chamaethrix was Leptolyngbya sp. CR_17M with similarity in $16 \mathrm{~S}$ rRNA $95.5 \%$. The node connecting these two branches had maximal posterior probability support, but it was only weekly supported by bootstrap resampling tests. Chamaethrix is only distantly related to Leptolyngbya sensu stricto, with numerous intervening genera such as Tapinothrix, Plectonema, Pseudophormidium, Plectolyngbya, and Phormidesmis, as well as phylogenetically uncertain Leptolyngbya-like strains, with no species level identification.

An inference of 16S-23S ITS secondary structure provided another unique feature of Chamaethrix. The D1-D1' helix is peculiar by both structure and unusual length (113 bp). It possesses a similar basal part as other Leptolyngbya-like cyanobacteria (see ZAMMIT et al. 2012 and Osorio-SANTOS et al. 2014) characterized by unilateral bulge. However, Chaemothrix possesses both a large ( $22 \mathrm{bp}$ ) and small *8) loop, not seen in other taxa (Fig. 3). Both tRNA coding isoleucine and alanine are present.

\section{Discussion}

Leptolyngbya is amongst the most widely distributed, ecologically permissive, commonly encountered, yet polyphyletic genera of cyanobacteria. Recently, a substantial effort to revise the Leptolyngbya sensu lato has begun, with the erection of several new genera (e.g. Perkerson et al. 2011; Osorio-SAntos et al. 2014; MisCOE et al. 2016). However, as our phylogenetic analysis shows (Fig. 2), revisions are far from complete. Only a handful of lineages have thus far been proposed (Nodosilinea, Oculatella, and Stenomitos), still leaving $>100$ species. Furthermore, there is still undiscovered diversity in Leptolyngbya-like cyanobacteria and we propose a new monospecific genus found in subtropical soil crust.

Several lines of evidence led us to establish a new monospecific genus. First, phylogenetic inference revealed that Chamaethrix forms a distant clade from Lepolyngbya sensu stricto within a group of Leptolyngbya-like cyanobacteria without specific designation and Arthronema africana. The closest relative of Chamaethrix was Leptolyngbya sp. CR_17M. Based on the 16S rRNA similarity, these two strains may be included in one genus (STACKERBRANDT \& EBERS 2006; KIM et al. 2014), which is also supported by the phylogeny. Unfortunately, we were unable to obtain any morphological data from Leptolyngbya sp. CR_17M since it has not been published, only the habitat (a thermal spring). However, this strain may be included in Chamaethrix in the future if warranted.

Second, although we found five Leptolyngbya-like species forming thick blackish sheathes, Chamaethrix differed in one or more key morphological characteristics from all these taxa. Four of the taxa (L. nigracans, AnAgnostidis \& KomÁreK 2005; L. nigrescens, KomÁreK 2007; L. badia, JoHANSEN et al. 2008 and L. sieminskae, Richter \& MATUla 2013) had smaller cells width $(0.8-1.5 \mu \mathrm{m})$. In terms of cell dimension and morphology, the most similar species was Lyngbya fusco-vaginata (STARMACH 1995), which, based on the description belongs to the genus Leptolyngbya sensu AnAGNOSTIDIs \& KOMÁREK (2005), but it has not been formerly transferred to Leptolyngybya. However, we cannot proceed with the revision without a culture and/or sequence data. Chamaethrix possesses cells $2.8 \pm 0.5 \mu \mathrm{m}$ wide, which slightly overlaps with 2-2.4 $\mu \mathrm{m}$ of Lyngbya fusco-vaginata, but Chamaethrix has thicker filaments $(3.63-4.67 \mu \mathrm{m}$ in contrast 


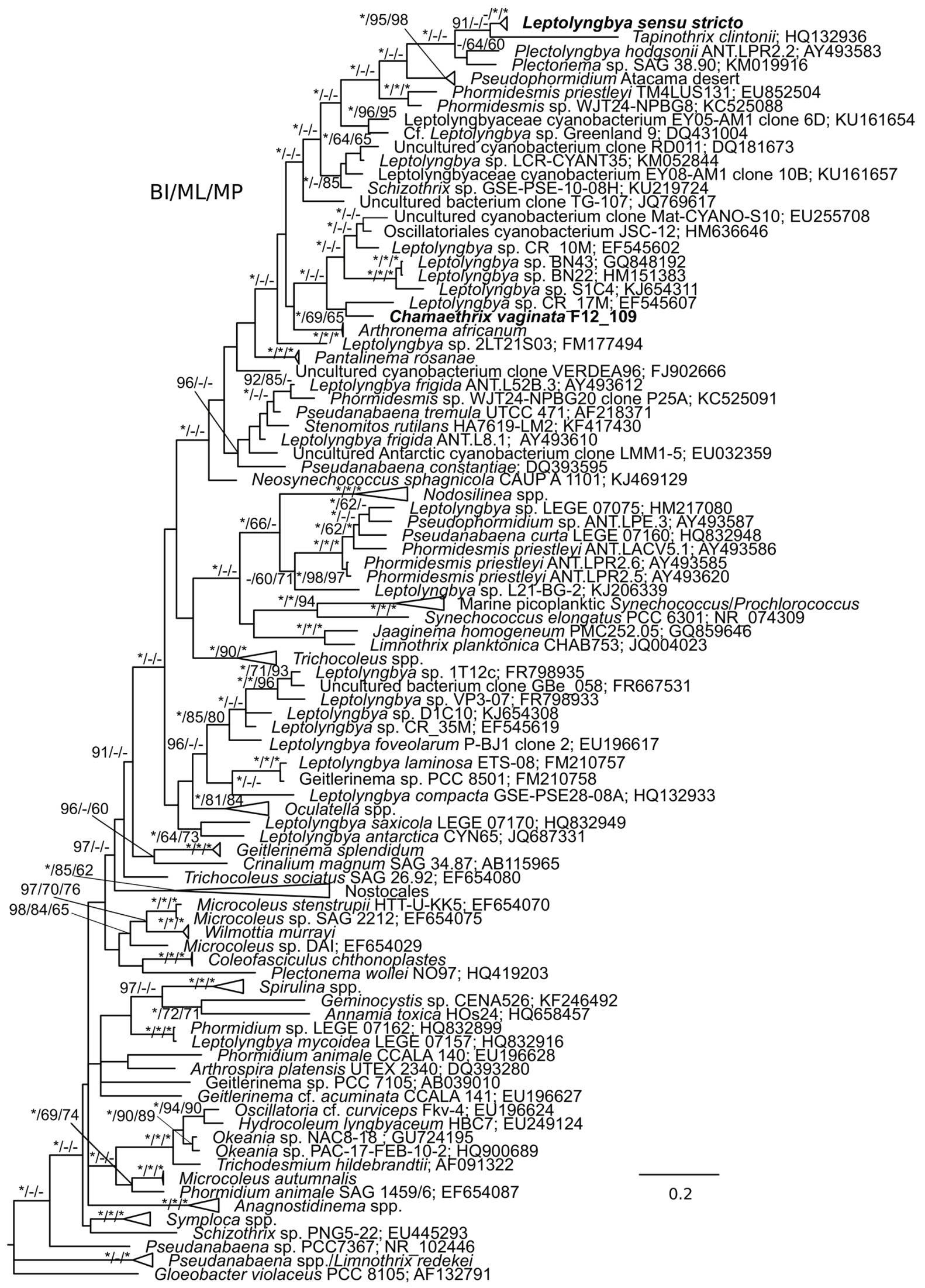

Fig. 2. Bayesian phylogenetic reconstruction of cyanobacteria focused on the genus Leptolyngbya based on 16S rRNA partial sequence of 144 taxa. Node support are following: posterior probabilities from Bayesian inference/maximum likelihood/maximum parsimony; asterisk represent values above 98; only values higher than 90 (posterior probabilities) and 60 (bootstrap support) are listed. Studied strain is in bold. 


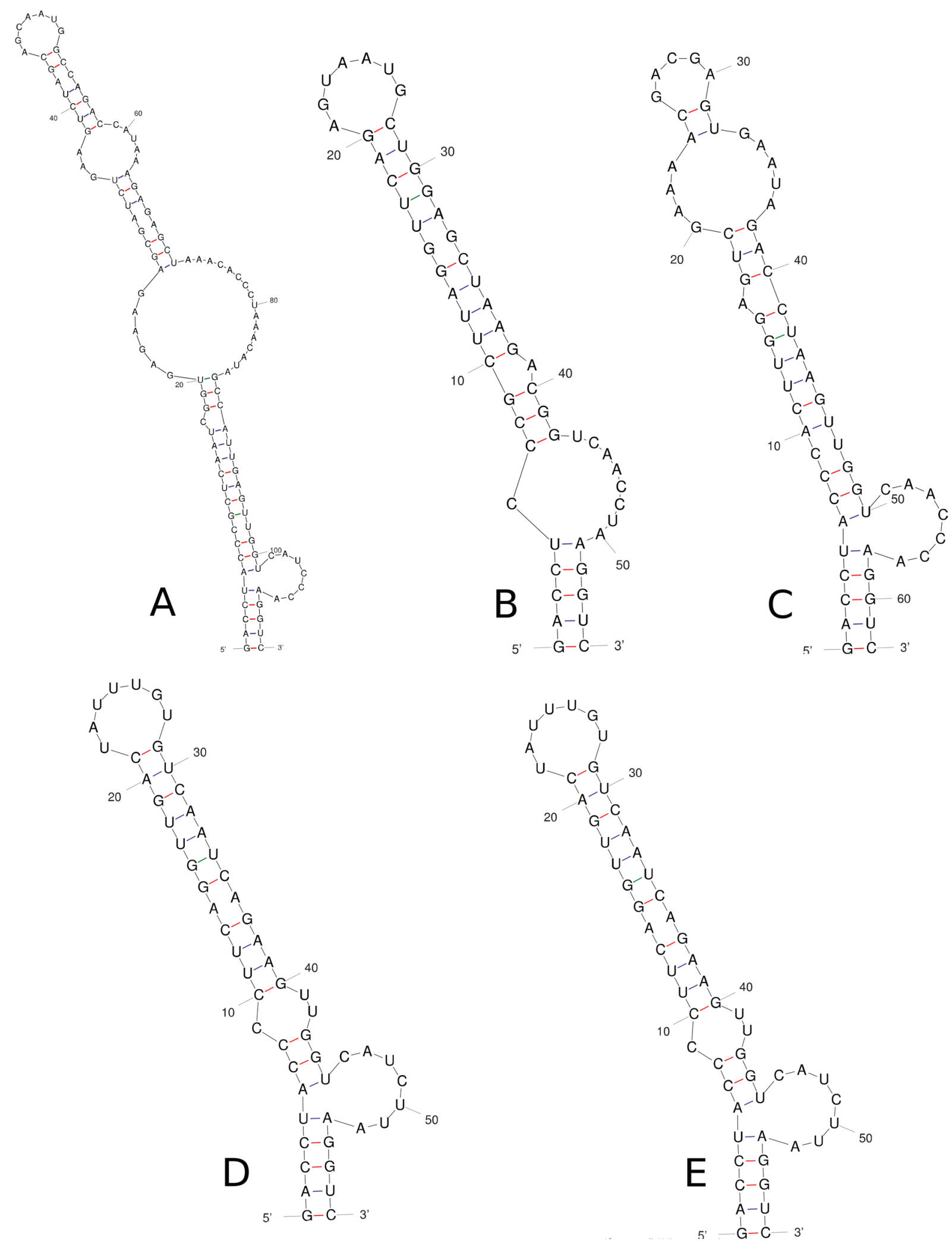

Fig. 3. A reconstruction of secondary structure of D1-D1' helices within the 16S-23S ITS of Chamaethrix vaginata and related sister-taxa: (a) C. vaginata gen. nov.; (b) Schizothrix sp. (KU219724.1); (c) Phormidesmis sp. WJT36-NPBG18 (KJ939042.1); (d) Leptolyngbya boryana UTEX488 (KJ939016.1); (e) L. boryana PCC6306 (KJ939014.1). 
with maximum $3 \mu \mathrm{m}$ in Lyngbya fusco-vaginata). Moreover, none of mentioned species possesses two trichomes tightly attached in a common sheath, which is a feature that distinguishes Chamaethrix among Leptolyngbya-like cyanobacteria. This feature is typical for the genus Blennothrix, but Blennothrix belongs to Oscillatoriales (KOMÁREK et al. 2014), and all members are obligatorily larger $(8 \mu \mathrm{m})$ and undertake a specific form of reproduction. Third, mentioned species were isolated from Antarctica (except of L. badia), which sharply contrasts with subtropical origin of Chamaethrix. Fourth, 16S-23S ITS structures largely differ from available sequences from Leptolyngbya-like cyanobacteria and Leptolyngbya sensu stricto.

Higher level taxonomic units, such as orders and families, are currently under revision and reorganization in the cyanobacteria. Komárek et al. (2014) recognize five cyanobacterial orders, with Leptolyngbya classified in the order Synechococcales (parietal thylakoids) and family Leptolyngbyaceae (single filaments in a sheath). Considering the phylogenetic position of Chamaethrix, we may conclude that it belongs to the same family and order. However, we note that the Synechococcales is not a monophyletic group, and therefore its status may be reevaluated in the future.

We report a new monospecific genus morphologically similar to Leptolyngbya-like cyanobacteria. It seems that relationships within this group are more complicated than previously expected. Considering a number of polyphyletic lineages, Leptolyngbya exhibits similar pattern like Synechococcus (Dvoř́́K et al. 2014). Thus, we may anticipate large revisions and possibly more new taxa arising within this enigmatic group.

\section{ACKnowledgements}

PD would like to express his gratitude to his lovely wife Eva Dvořák Tomaštíková (Swedish University of Agricultural Sciences), who was the best accompaniment on the sampling expedition. The name was edited by Lubor Kysučan. Chelsea Villanueva provided the folded ITS structures. This study was supported by IGA UP Prf-2017-001.

\section{ReferenCES}

Anderson, A.R. (2005): Algal culturing techniques. - 578 pp., Elsevier Academic Press

Anagnostidis K. \& KomÁreK, J. (1988): Modern approach to the classification system of cyanophytes 3. Oscillatoriales. - Algological Studies 50-53: 327-472.

Boyer, S.L.; Fletchner, V. \& Johansen, J.R. (2001): Is the 16S-23S rRNA internal transcribed spacer (ITS) region a good tool for use in molecular systematics and population genetics? A case study in cyanobacteria. - Mol. Biol. Evol. 18: 1057-1069.

Boyer, S.L.; Johansen, J.R. \& Howard, G.L. (2002): Phylogeny and genetic variance in terrestrial Microcoleus (Cyanophyceae) species based on sequence analysis of the 16S rRNA gene and associated 16S-23S ITS region. - J. Phycol. 38: 1222-1225.
DvoŘÁK，P.; Casamatta，D.A.; Hašler，P.; OndŘEJ，V.; PoulíčKová, A. \& Sanges, R. (2014): Synechococcus: 3 billion years of global dominance. - Mol. Ecol. 23: 5538-5551.

Dvořák, P.; PoulíčKová, A.; Hašler, P.; Belli, M.; CasamatTA, D.A. \& PAPINI, A. (2015): Species concepts and speciation factors in cyanobacteria, with connection to the problems of diversity and classification. - Biodivers. Conserv. 24:739-757.

DvořÁk, P.; HašLer, P. \& PoulíčKovÁ, A. (2012): Phylogeography of the Microcoleus vaginatus (cyanobacteria) from three continents - a spatial and temporal characterization. - PLoS ONE7: e40153. doi:10.1371/ journal.pone.0040153.

Dvořák, P.; Casamatta, D.A.; Hašler, P.; JahodÁŘová, E.; Norwich, A.R. \& PoulíčKovÁ, A. (2017): Diversity of the cyanobacteria. - In: Hallenbeck, P. (ed.): Modern Topics in the Phototrophic Prokaryotes. Springer International Publishing, (in press).

EDGAR, R.C. (2004): MUSCLE: multiple sequence alignment with high accuracy and high throughput. - Nucleic Acids Res. 32: 1792-1797.

Fiore, M.F.; Sant'Anna, C.L.; Azevedo, M.T.P.; KomÁrek, J.; KaštovskÝ, J.; Sulek, J. \& LoREnZI, A.S. (2007): The cyanobacterial genus Brasilonema - molecular and phenotype evaluation. - J. Phycol. 43: 789-798.

Hašler, P.; Dvořák, P.; PoulíčKová, P. \& CASAmatta, D.A. (2014): A novel genus Ammassolinea gen. nov. (Cyanobacteria) isolated from subtropical epipelic habitats. - Fottea 14: 241-248.

Hašler, P.; Casamatta, D.; Dvořák, P. \& PoulíčKová, A. (2017): Jacksonvillea apiculata (Oscillatoriales, Cyanobacteria) gen. \& sp. nov.: a new genus of filamentous, epipsamic cyanobacteria from North Florida. - Phycologia 56: 284-295.

Johansen, J.R.; Olsen, C.E.; Lowe, R.L.; FucíkovÁ, K. \& CASAmatTA, D.A. (2008): Leptolyngbya species from selected seep walls in the Great Smoky Mountains National Park. - Algological Studies 126: 21-36.

Kim, M.; Оh, HS; PARK, SC. \& Chun, J. (2014): Towards a taxonomic coherence between average nucleotide identity and 16S rRNA gene sequence similarty for species demarcation of prokaryotes. - Int. J. Syst. Evol. Microbiol. 64: 346-351

KomÁreK, J. (2007): Phenotype diversity of the cyanobacterial genus Leptolyngbya in maritime Antarctica. Pol. Polar Res. 28: 211-231.

KomÁreK, J. \& AnAgnostidis, K. (2005): Cyanoprokaryota. 2. Teil: Oscillatoriales. - In: BÜDEL, B.; GÄRDNER, G.; Krienitz, L. \& Schagerl. M. (eds): Süswasserflora von Mitteleuropa, vol. 19/2. - 759 pp., Elsevier, München.

KomÁrek, J.; Kaštovský, J.; Mareš, J. \& Johansen, J.R. (2014): Taxonomic classification of cyanoprokaryotes (cyanobacterial genera) 2014 using a polyphasic approach. - Preslia 86: 295-335.

Larkin, M.A.; Blackshields, G.; Brown, N.P.; Chenna, R.; McGettigan, P.A.; McWillia, H.; Valentin, F.; Wallace, I.M.; Wilm, A.; Lopez, R.; Thompson, J.D.; Gibson, T.J. \& Higgins. D.G. (2007): Clustal $\mathrm{W}$ and Clustal X version 2.0. - Bioinformatics 23: 2947-2948.

Miscoe, L.H.; Johansen, J.R.; Kociolek, J.P.; Lowe, R.L.; Vaccarino, M.A.; Pietrasiak, N. \& Sherwood, A.R. (2016): The diatom flora and cyanobacteria from 
caves on Kauaia, Hawaii. Taxonomy, distribution, new species. - In: Bibliotheca Phycologica 120. 152 pp., J. Cramer, Stuttgart.

Osorio-Santos, K.; Pietrasiak, N.; Bohunická, M.; Miscoe, L.H.; Kovácik, L.; Martin, M.P. \& Johansen, J.R. (2014): Seven new species of Oculatella (Pseudanabaenales, Cyanobacteria). - Eur. J. Phycol. 49: 450-470.

Perkerson, R.B.; Johansen, J.R.; Kováčí, L.; Brand, J.; KaštovskÝ, J. \& CASAmatTA, D.A. (2011): A unique pseudanabaenalean (cyanobacteria) genus Nodosilinea gen. nov. based on morphological and molecular data. - J. Phycol. 47: 1397-1412.

PosadA, D. (2008): jModelTest: phylogenetic model averaging. - Mol. Biol. Evol. 25: 1253-1256.

Richter, D. \& MAtula, J. (2013): Leptolyngbya sieminskae sp. n. (Cyanobacteria) from Svalbard. -

Pol. Polar Res. 34: 151-168.

Rippka, R.; Deruelles, J.; Waterbury, JB.; Herdman, M. \& StANIER, R.Y. (1979): Generic assignments, strain histories and properties of pure cultures of cyanobacteria. - J. Gen. Microbiol. 111:1-61.

Ronquist, F. \& Huelsenbeck, J.P. (2003): MRBAYES 3: Bayesian phylogenetic inference under mixed models. - Bioinformatics 19: 1572-1574.

Stackebrandt, E. \& Ebers, J. (2006): Taxonomic parameters revisited: tarnished gold standards. -Microbiol. To- day $33: 152-155$

StAMATAKIS, A. (2006): RAxML-VI-HPC: maximum likelihood-based phylogenetic analyses with thousands of taxa and mixed models. - Bioinformatics 22: 26882690.

Starmach, K. (1995): Freshwater algae of the Thalla Hills oasis (Enderby land, East Antarctic). - Pol. Polar Res. 16: 113-148.

StAUB, R. (1961): Research on physiology of nutrients of the planktonic cyanobacterium Oscillatoria rubescens. Schweiz. Zeitsch. Hydrol. 23: 83-198.

Swofford, D.L. (2002): PAUP*: Phylogenetic Analysis Using Parsimony (*and other methods), version 4. Sunderland, MA: Sinauer Associates.

Tamura, K.; Stecher, G.; Peterson, D.; Filipski, A. \& KuMAR, S. (2013): MEGA6: Molecular Evolutionary Genetics Analysis Version 6.0. - Mol. Biol. Evol. 30: 2725-2729.

Zammit, G., Billi, D. \& Albertano, P. (2012): The subaerophytic cyanobacterium Oculatella subterranea (Oscillatoriales, Cyanophyceae) gen. et sp. nov.: a cytomorphological and molecular description. - Eur. J. Phycol. 47:341-354

ZuCKer, M. (2003): Mfold web server for nucleic acid folding and hybridization prediction. - Nucl. Acids Res. 31: 3406-3415.

(C) Czech Phycological Society (2017)

Received January 6, 2017

Accepted July 13, 2017 